Open Access

\title{
Does the future of a farm depend on its neighbourhood? Evidence on intra-family succession among fruit and vegetable farms in Italy
}

\author{
Daniele Cavicchioli ${ }^{*} \mathbb{D}$, Danilo Bertoni, Dario Gianfranco Frisio and Roberto Pretolani
}

\author{
* Correspondence: daniele. \\ cavicchioli@unimi.it \\ Department of Environmental \\ Science and Policy, Università degli \\ Studi di Milano, Via Celoria, 2, 20133 \\ Milan, Italy
}

\begin{abstract}
The transfer of farm activity over time occurs through different pathways, among which the more frequent is intra-family farm succession. Thus, better information on farm succession determinants is crucial for understanding farm succession and informing appropriate sectoral policies. To date, substantial research has focused on the effect of farm, farmer and potential heir features on farm succession, while the role played by socio-economic conditions around a farm has been relatively less examined. Building on previous contributions, the present paper considers farm succession as the opposite of labour migration out of the agricultural sector. Thus, the effect of the labour market and surrounding conditions (LMSC) around a farm on its succession probability is explored. The aim of this paper is therefore to explore whether and to what extent the inclusion of LMSC variables may contribute to a better understanding of farm succession. Using data from a sample of 266 fruit and vegetable farms (gathered for informative purposes by a producers' organization consortium), empirical evidence that LMSC variables play an important role in explaining the succession probability in these types of farms is provided. Specifically, the results show that (i) including LMSC variables in a farm succession analysis increases the explanatory power and robustness of the model estimates; (ii) LMSC variables have a non-linear effect on succession; and (iii) some explanatory variables (farmer education and farm age, specialization and dimension) are significant across various specifications, while other variables (farmer age, territorial location and distance of a farm from its producer organization) change their sign and/or significance when LMSC variables are included in the model. As a consequence, our findings suggest that LMSC variables should be included in farm succession and labour market analysis to provide a better estimate of farm succession probability.
\end{abstract}

Keywords: Farm transfer, Local labour market, Out-farm migration, Occupational choice theory

JEL classification codes: J62, J43, Q12, R12 


\section{Background}

Agriculture in Italy and Europe involves farms that are predominantly family-owned (Graeub et al. 2016). For this reason, intra-family succession is the preferred mechanism to transfer farm management to future generations (Lobley et al., 2010; Leonard et al. 2017; Chiswell 2018). Even if evidence of farm performance after intra-family succession is not univocal (Bertoni et al. 2017; Carillo et al. 2013), generational turnover and renewal in agriculture is still largely assured by this process. Thus, an in-depth analysis of the mechanisms and determinants of intra-family succession is relevant to addressing the multiple challenges that Italian and European agriculture will face in future decades.

The relevance of this issue is based on at least three important issues that are widely debated in the literature: (i) the capacity of intra-family farm succession to ensure an adequate turnover in agriculture and to address the ageing population of farmers, (ii) the consequences of high/low rates of farm succession, and finally, (iii) the relationship between farm succession and rural migration.

The first issue pertains to the progressive ageing of the farmer population, particularly in developed countries where there is a shortage of young farmers, or even a farm succession crisis (Zagata and Sutherland 2015; Burton and Fischer 2015). This problem is evident in Italy, where according to Eurostat data from 2016, 41\% of farms, representing $27 \%$ of the total agricultural area, are managed by farmers aged 65 years or over $(65 \%$ of farms and $50 \%$ of the agricultural area managed farmers aged 55 years or over). Whether a succession crisis is taking place in the agricultural sector is debatable, considering that official statistics do not record information on farm succession. Based on information from ad hoc surveys, the FARMSTRANSFER project (Errington 1998; Uchiyama et al. 2008; Lobley et al., 2010; Chiswell and Lobley 2015) indicates that succession rates are satisfactory. Nevertheless, in particular contexts such as marginal areas or areas with a high incidence of small farms, more critical situations may emerge. Similarly, Zagata and Sutherland (2015) examined young farmer shortages in Europe using Eurostat data.

Another topic of debate in terms of succession in agriculture pertains to the potential consequences of the lack of successors in agriculture and for ageing farmers. Opinions differ on this point. Some believe that low succession rates should not necessarily be considered a negative phenomenon, as in more productive areas, farms without successors can be absorbed by farms that are maintained, favouring economies of scale (Chiswell and Lobley 2015; Glauben et al. 2006). Other authors argue that, especially in marginal areas, the lack of succession can translate into abandonment of territory and loss of farm-specific knowledge and human capital accumulated and transmitted by previous generations, with a risk of environmental and territorial degradation (MacDonald et al. 2000; Corsi 2009; Raggi et al. 2013; Demartini et al. 2015).

However, several authors agree that young farmers are more inclined towards entrepreneurship (Vesala and Vesala 2010; McDonald et al. 2014; Stenholm and Hytti 2014), farm business diversification (McElwee and Bosworth 2010; Grubbström et al. 2014; Suess-Reyes and Fuetsch 2016; Ohe 2018) and adoption of eco-sustainable farming practices (Van Passel et al. 2007; Bertoni et al. 2011; Paracchini et al. 2015; Hamilton et al. 2015; Suess-Reyes and Fuetsch 2016). 
Finally, the issue of farm succession clearly intersects with the wider abandonment of rural areas by younger people. Although the two phenomena do not completely overlap, they are connected, and farm succession trajectories can be considered a part of this larger phenomenon, especially in areas characterized by high agricultural employment (Bertoni and Cavicchioli 2016b). Several studies analysed the motivations behind the intentions of potential heirs to abandon agricultural activity and/or rural areas (Morais et al. 2017, 2018; Bednař́ková et al. 2016; Chen et al. 2014; Bjarnason and Thorlindsson 2006). In particular, this trend seems to be strengthened among young people with a higher level of education (Bednaríková et al., 2016) and, other things being equal, women (Leibert 2016; Johansson 2016).

For the above-mentioned reasons, understanding the mechanisms and determinants of farm succession is relevant for assuring continuity in agricultural activities. A large part of the literature on farm succession is devoted to analysing the process of farm succession using both qualitative and quantitative approaches (Bertoni and Cavicchioli 2016b). Quantitative papers on farm succession rely on estimating the timing of succession, the effect of succession on farm assets/performance and mainly the probability and determinants of farm succession. Specifically, this last type of literature focuses on isolating the factors affecting the probability of farm transfer. Such analyses exploit limited dependent variable regression (probit or logit) using the event of farm succession as a dependent variable (1, succession takes place; 0 , succession does not take place). This type of event may be observed directly (following a sample or a population of farms over a long time span, Stiglbauer and Weiss 2000) or may be inferred by asking a farmer his/her expectations about farm transfer (Glauben et al., 2004). In the former case, the information is more reliable, while data based on farmer statements may be inconsistent with respect to the actual event of succession (Väre et al. 2010). Most of the analyses have been carried out at the farm level, while few have focused on the probability that each potential heir in a family farm will take over the farm (Simeone 2006; Mann 2007; Aldanondo Ochoa et al. 2007).

The main part of farm succession literature focuses on the effect of farm, farmer and potential heirs features on the probability that succession takes place (Stiglbauer and Weiss 2000; Kimhi and Nachlieli 2001; Simeone 2006; Glauben et al. 2009; Cavicchioli et al. 2015), paying less attention to the effect exerted by socio-economic conditions around the farms examined, with some notable exceptions (Glauben et al., 2004, Aldanondo Ochoa et al. 2007; Corsi 2009; Kerbler 2008). To account more explicitly for the effect of the economic environment around the farm, some recent contributions (Bertoni and Cavicchioli 2016a; Cavicchioli et al. 2018) have treated the phenomenon of farm succession as the opposite choice with respect to searching for alternative employment outside of the farm sector. This decision has been previously modelled within the occupational choice theory (OCT-Todaro 1969; Harris and Todaro 1970; Mundlak, 1978; Barkley 1990 and Larson and Mundlak 1997). According to this theory, the probability of searching and finding a job in another sector is (linearly) fostered by the income gap between sectors: the larger the spread between the sectors (e.g., agriculture and non-agricultural activities) is, the higher the incentive for an individual to migrate out of the sector of origin. OCT also states that the income gap between sectors is a necessary but not sufficient condition for labour mobility, as other variables may increase or decrease the transaction costs for finding employment outside of the 
original sector. Such variables are population density, employment rate, and the relative dimensions (in labour size) of the economic sectors where the migration takes place. Considering, for example, labour migration from agricultural to non-agricultural sectors, such a process, according to OCT, is favoured in areas with higher population densities that offer more occasions to find a job. Similarly, the higher the employment rate in the local labour market, the higher the probability that agricultural workers will find jobs in non-agricultural sectors. Finally, the smaller the relative labour size of the agricultural sector (intended as the number of agricultural workers with respect to non-agricultural workers), the higher the employment opportunities will be in non-agricultural sectors for labourers coming from farming activities.

A recent analysis of the effect of agricultural payments on off-farm labour migration was based on OCT (Olper et al. 2014), with results consistent with theoretical expectations. Treating farm succession as an alternative to off-farm migration allows a bridge between a traditional farm succession analysis and OCT. Because farm transfer represents the opposite choice with respect to finding a job outside of the agricultural sector, the expected effect of local labour market variables (income gap, population density, employment and relative labour size of an agricultural sector) on farm transfer should be the opposite of those predicted by OCT. Thus, if OCT predicts a positive effect of income gap, population density, employment rate and relative labour size of the farm sector on agricultural labour migration, then increasing values of these variables are expected to discourage farm succession. The use of the variables suggested by OCT in farm succession analyses has yielded some unexpected results; according to OCT, local labour market variables should exert a linear effect on labour migration, but the effect of these variables in farm succession analyses were non-linear (Bertoni and Cavicchioli 2016a; Cavicchioli et al. 2018). The authors explained such unexpected outcomes as a combination of pro-succession and anti-succession effects for increasing values of local labour market variables.

The aim of this paper is therefore to better understand whether and to what extent the inclusion of LMSC variables may contribute to a better understanding of farm succession. This paper is based on a traditional farm succession analysis, as it uses farm and farmer features to explain farm transfer; furthermore, in continuity with recent studies (Bertoni and Cavicchioli 2016a; Cavicchioli et al. 2018), it contributes to the literature by accounting explicitly for the interaction between farm and farmer characteristics with labour market and surrounding conditions (LMSC) on farm succession predictions. By including the latter group of variables, intra-family farm succession was modelled as an alternative to searching for employment in non-agricultural sectors. With respect to previous studies that used OCT in farm succession analyses, in this study, the empirical exercise was carried out on a larger sample of fruit and vegetable farms. An additional contribution of this study, in comparison to similar previous analysis, is to assess whether and to what extent the inclusion of LMSC variables improves the prediction of farm succession in terms of estimation accuracy.

This analysis explores the following factors: $(i)$ whether LMSC variables affect farm succession, ( $i i)$ whether their effect is linear or non-linear, and (iii) whether and to what extent the inclusion of such variables improves the prediction of farm succession in comparison to a traditional farm succession analysis, based mainly on farm and farmer features. 
The remainder of the paper is organized as follows: the "Data and methodology" section shows the sample data and methodology used to carry out the empirical exercise, presenting the different models (with and without LMSC variables) and explaining the post-estimation tests for model comparison. The "Results and discussion" section presents and discusses the results of the different models used to predict farm succession, in addition with post-estimation comparisons. The "Concluding remarks" section outlines the main conclusions.

\section{Data and methodology}

\section{Data and variables}

As mentioned in the introduction, detecting farm succession is difficult, considering the lack of official data on this process. Thus, the present analysis focused on a group of farms for which such information was available.

The empirical exercise to test the above-mentioned hypotheses was carried out using data from a 2010 survey of fruit and vegetable farms belonging to a consortium of producers' organizations (POs). It is worth noting that such a survey was originally designed by the $\mathrm{PO}$ consortium for informative purposes and not for research aims. Therefore, the survey was intended to provide a detailed picture of farms belonging to the consortium, with detailed questions on crop mix and production. Researchers have been involved only in designing the part of the questionnaire devoted to human capital and farm succession perspectives. The pilot questionnaire was pre-tested and validated at the beginning of 2010 on a limited number of farms representing the main typologies of the entire population. The validated questionnaire was administered to all farms over 2010. Both the pilot and final questionnaires were administered face-to-face by technicians of the consortium to farm holders. The information on farm succession perspectives allowed us to infer farm succession probabilities. Unfortunately, as the questionnaire was mainly designed for informative purposes for the PO consortium, some explanatory variables, usually employed in farm succession analysis literature, were not collected. Thus, these missing variables have been replaced by other available proxies in the subsequent analysis.

Furthermore, the database from which data have been drawn covered all the farms that were members of the PO consortium (603 farms); as farm-level data on farm membership in producers organizations (and their consortia) are not publicly available, it is difficult to establish to what extent the collected data may be representative of all fruit and vegetable farms that are members of POs in Italy. For the same reason, the extendibility of the results is not straightforward.

From all the surveyed members of the PO consortium (603), a sample of 266 farms with farm-holders older than 45 years old with at least one child aged 15 years or older was selected. Such criteria were adopted to ensure that farms that have considered and/or are planning on farm succession were selected. Thus, we excluded farms without potential successors or siblings that were too young on the family farm.

The event of family business transfer in the sample was treated as a dichotomous variable, inferred from farm-holder expectation on whether farm succession would take place in the future. It is worth remembering that such expectations may not result in 
actual behaviour (Väre et al. 2010). As the aim of the analysis was to explore the improvement in farm succession estimations brought by labour market and surrounding conditions (LMSC) variables, in comparison to farm and farmer features, both the former and the latter have been selected as explanatory variables. The description of the variables is included in Table 1 in addition to the justification for their inclusion in the analysis, which was based on previous literature.

The explanatory variables in Table 1 are classified as belonging to the farm, farmer or LMSC variables. Farm and farmer variables have been selected as a compromise between evidence from previous literature on farm succession (listed in the last column of Table 1) and data availability. As the survey from which the dataset was developed was not designed for research purposes, it was necessary to select some proxy variables that were as similar as possible to those suggested by the literature. In particular, among farm-level information, available data on farm size, both in economic (Turnover_250, expressed as a dummy variable) and in structural terms (Workdays), have been selected. Furthermore, two dummy variables (RPFV farm and Fruit farm) were selected to capture the heterogeneity in farm production within the sample.

Labour market and surrounding conditions (LMSC) variables (income gap, population density, employment rate and share of agricultural labour) were calculated at the local labour system level. According to the Italian Institute for Statistics (ISTAT), a local labour system is an area (groups of municipalities) with homogeneous features in terms of supply and demand of labour (for further information, see www.istat.it/en/ archive/142790). Therefore, LMSC variables have been calculated and associated with the local labour system of each farm in the sample. Notably, in Table 1, variables not suggested by occupational choice theory, such as Distance (the distance of the farm from the headquarter of the producer organization) and various territorial locations of the farm (Hills, Mountain and regional dummies), are classified as LMSC variables. The inclusion of such variables is suggested by the literature and is necessary to capture site-specific characteristics of the areas surrounding a farm. Even if the present contribution takes advantage of the theoretical insights from occupational choice theory, there is not yet a unifying theoretical framework suggesting which variables should be included or excluded in the empirical exercise to test farm succession determinants. Thus, among the variables available in the dataset, we selected those that were relevant in previous literature under different specifications. In so doing, it was possible to test the three research questions mentioned above and to isolate farm succession determinants with effects that are more stable across various specifications.

The sample contains 266 farms of which 113 with farmers that declared succession and 153 with farmers that did not expect an intra-family succession of the farm business. Table 2 reports descriptive statistics for each variable of the sample and is split into farms with and without (expected) succession.

\section{Methodology}

As described in the background section, the main contribution and emphasis of the present paper is to explore whether and to what extent labour market variables and surrounding conditions (LMSC) around a farm affect succession probability and improve its estimation. These research questions informed the empirical strategy that was 


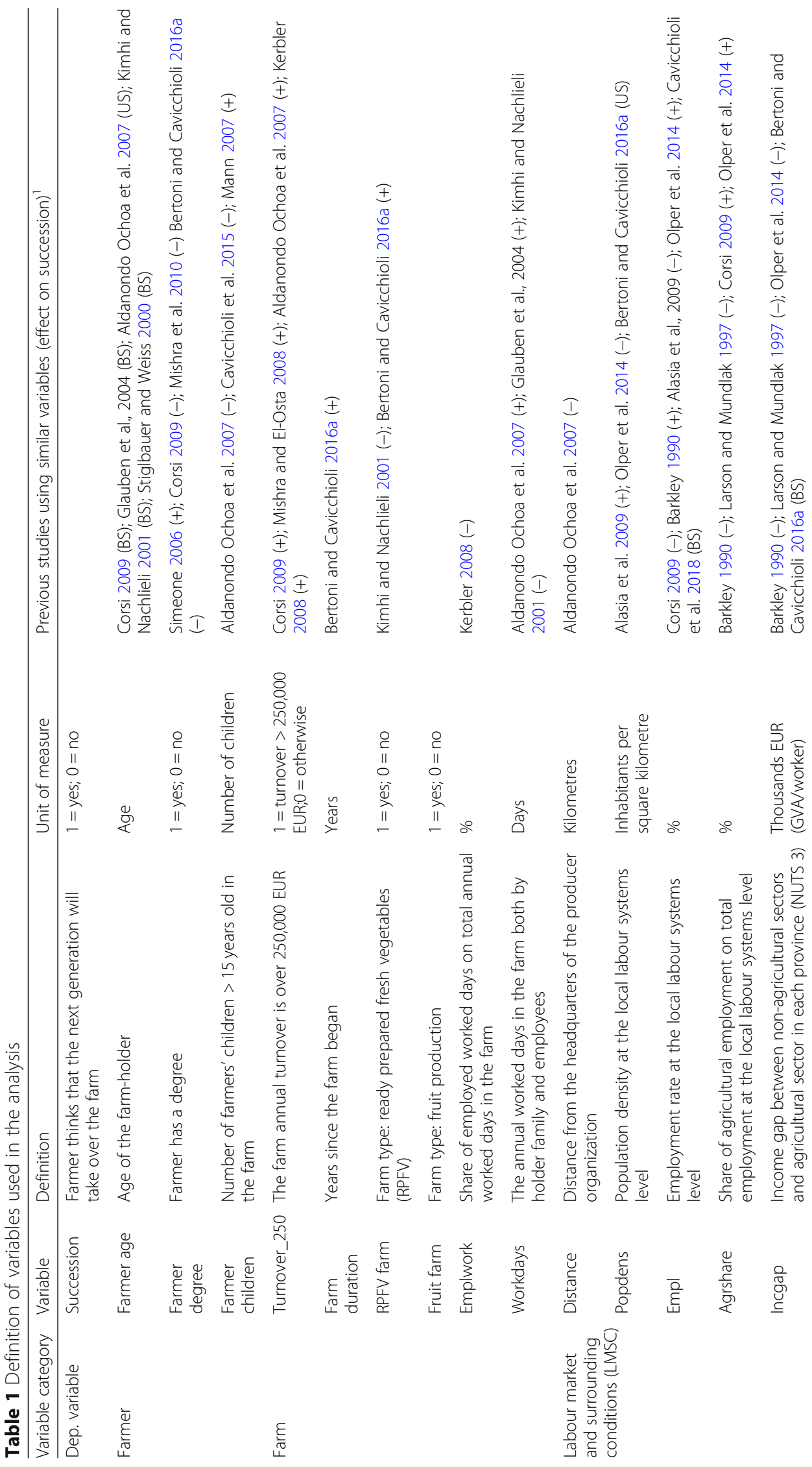




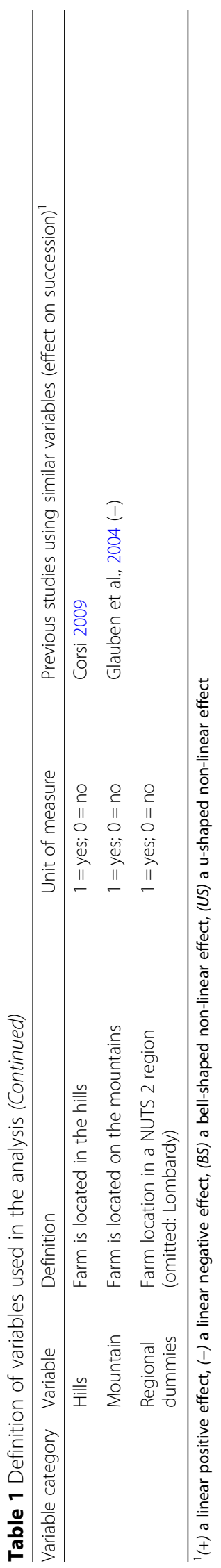


Table 2 Descriptive statistics of the sample

\begin{tabular}{|c|c|c|c|c|c|c|}
\hline \multirow[t]{2}{*}{ Variable } & \multicolumn{2}{|c|}{$\begin{array}{l}\text { Total farms in the sample } \\
(n=266)\end{array}$} & \multicolumn{2}{|c|}{$\begin{array}{l}\text { Farms with succession } \\
(n=113)\end{array}$} & \multicolumn{2}{|c|}{$\begin{array}{l}\text { Farms without succession } \\
(n=153)\end{array}$} \\
\hline & Mean & Std. dev. & Mean & Std. dev. & Mean & Std. dev. \\
\hline Succession & 0.42 & 0.50 & & & & \\
\hline Farmer age & 56.04 & 9.56 & 55.76 & 10.63 & 56.29 & 8.68 \\
\hline Farmer degree & 0.05 & 0.21 & 0.04 & 0.19 & 0.05 & 0.22 \\
\hline Farmer children & 2.55 & 1.56 & 2.93 & 1.76 & 2.30 & 1.34 \\
\hline Turnover_250 & 0.30 & 0.46 & 0.17 & 0.38 & 0.40 & 0.49 \\
\hline Farm duration & 32.85 & 22.71 & 35.68 & 23.39 & 29.68 & 21.24 \\
\hline RPFV farm & 0.23 & 0.42 & 0.38 & 0.49 & 0.12 & 0.33 \\
\hline Fruit farm & 0.38 & 0.49 & 0.22 & 0.42 & 0.52 & 0.50 \\
\hline Emplwork & 25.73 & 32.93 & 33.71 & 34.14 & 20.00 & 31.04 \\
\hline Workdays & 966.5 & 1206.1 & 1332.4 & 1407.6 & 696.3 & 965.6 \\
\hline Distance & 55.29 & 138.31 & 66.61 & 149.29 & 49.43 & 132.98 \\
\hline Popdens & 298.2 & 429.8 & 365.4 & 403.9 & 242.4 & 420.2 \\
\hline Empl & 47.64 & 4.09 & 46.89 & 5.00 & 48.07 & 3.28 \\
\hline Agrshare & 5.85 & 3.29 & 5.53 & 2.92 & 6.04 & 3.53 \\
\hline Incgap & 29.68 & 9.27 & 27.22 & 8.99 & 31.70 & 9.15 \\
\hline Hills & 0.04 & 0.21 & 0.09 & 0.29 & 0.01 & 0.11 \\
\hline Mountain & 0.38 & 0.49 & 0.24 & 0.43 & 0.50 & 0.50 \\
\hline \multicolumn{7}{|l|}{ Regional dummies } \\
\hline Campania & 0.13 & 0.33 & 0.22 & 0.42 & 0.07 & 0.25 \\
\hline Piemonte & 0.06 & 0.24 & 0.03 & 0.16 & 0.09 & 0.29 \\
\hline Veneto & 0.03 & 0.17 & 0.05 & 0.23 & 0.01 & 0.11 \\
\hline Emilia-Romagna & 0.03 & 0.18 & 0.04 & 0.21 & 0.03 & 0.16 \\
\hline
\end{tabular}

based on a limited dependent variable (probit) regression. This type of regression analysis yields estimated coefficients (odds ratios) that measure the effect of each explanatory variable on the succession probability. Therefore, three different specifications have been estimated:

- First specification (models 1, 2 and 3), including only farm and farm variables

- Second specification (model 4), including farm and farm variables and LMSC variables in linear form, as suggested by occupational choice theory

- Third specification (models 5, 6 and 7), including farm and farm variables and LMSC variables in non-linear form

The six models estimated in the first and third specifications differ for the introduction of squared terms in some continuous variables to test their possible non-linear effects. Overall, seven models have been estimated. For brevity purposes, the results of only three models (models 3, 4 and 7) are presented, one for each specification, in addition to post-estimation statistics. For the first and third specifications, the models that perform better in terms of prediction accuracy (pseudo $R$-square and share of correctly classified) were selected. The comparison of all seven models, in addition to their post-estimation statistics, is available as Additional file 1. 
In the first specification (models 1-3), we tested the effects of farm and farmer characteristics and of farm location in the hills or in the mountains (also defined as altimetry) and regional dummies. The effect of altimetry dummies was measured compared to the excluded altimetric band (plane). For instance, a positive and significant coefficient of "Hill" indicates a higher succession probability for farms located in hilly areas with respect to those in plain areas. The same reasoning applies to regional dummies, whose effect was compared to the excluded region (Lombardy).

As in the literature, some continuous variables (such as farmer age) are found to exert a non-linear effect on succession, which was tested both in models 1-3 and in models 4-6 for some continuous variables. In the second specification (model 4), LMSC variables-Popdens, Empl, Agrshare and Incgap-are entered in linear form, as suggested by occupational choice theory. In models $5-7$, the same variables are tested in polynomial (non-linear) form. This process is justified by previous findings (Bertoni and Cavicchioli 2016a, 2016b; Cavicchioli et al. 2018).

To compare different models, some statistical criteria that are widely used in the context of model selection are considered. Specifically, the pseudo $R$-square (see McFadden (1973), which is based on the likelihood ratio test, the scoring function (see Akaike 1974 and Schwarz 1978) and finally some classification results from the confusion matrix are used (Provost et al. 1998).

The pseudo $R$-square used in this analysis is McFadden's test. This test is based on a comparison between the log-likelihoods of two specifications: the full-model with predictors and the intercept model. Therefore, McFadden's $R$-squared measure can be defined as follows:

$$
R_{\text {McFadden }}^{2}=1-\frac{\ln \hat{L}\left(M_{\text {full-model }}\right)}{\ln \hat{L}\left(M_{\text {intercept }}\right)}
$$

where $\hat{L}$ denotes the maximized estimated likelihood value, while $M_{\text {full-model }}$ and $M_{\text {intercept }}$ denote the full-model predictors and the model with only an intercept, respectively. Thus, the ratio of the log-likelihoods suggests the level of improvement over the intercept model offered by the full model. Moreover, a small ratio of the likelihoods indicates that the full model provides a better fit than the intercept model, implying that McFadden's measure is higher for the model with the greater estimate of likelihood function.

The Akaike information criterion (AIC) and the Bayesian information criterion (BIC) represent alternative model selection tools. They are defined as follows:

$$
\begin{aligned}
& \mathrm{AIC}=-2 \ln (\hat{L})+2 k \\
& \mathrm{BIC}=-2 \ln (\hat{L})+2 \ln (N k)
\end{aligned}
$$

where $\ln (\hat{L})$ denotes the maximized estimated log-likelihood value related to the fullmodel predictors, and $k$ and $N$ are the total number of estimated parameters and observations, respectively. Both the AIC and the BIC indicators represent badness of fit measures; therefore, the optimal model is selected based on the minimum AIC and/or BIC. It is important to highlight that the BIC shows a larger penalty term to address the issue of the overfitting model. 
Finally, the confusion matrix consists of a predictive classification table, with the representation shown in Table 3:

Given the context of our analysis, we define an "event" as $r$ farm succession occurring or not occurring. If farm succession takes place, then the event is equal to 1 . If farm succession does not take place, then the event is equal to 0 . Therefore, the entries of the matrix, A, B, C and D have different meanings. Specifically, A is the number of correct predictions that farm succession takes place, $B$ is the number of incorrect predictions that farm succession takes place, $\mathrm{C}$ is the number of incorrect predictions that farm succession does not take place, and D is the number of correct predictions that farm succession does not take place.

Thus, the representation of the confusion matrix allows us to compute, for each estimated model, three types of conditional probabilities:

1. The sensitivity, which is defined as the $A /(A+C)$ proportion of events

2. The specificity, which is the $(D /(B+D))$ proportion of non-events

3. The accuracy (also known as the share of correctly classified), which is the $((\mathrm{A}+\mathrm{D}) / N)$ proportion of events correctly predicted by the model

Given the context of our analysis, the above-mentioned conditional probabilities (sensitivity, specificity and accuracy) in addition to the pseudo $R$-square and the information criteria (AIC and BIC) provide an intuitive measure of comparison among the models.

\section{Results and discussion}

The main results of the model estimates of farm succession are presented in Table 4, based on the estimation strategy presented in the "Methodology" section. Table 4 reports only three of the seven models estimated, which are presented in Additional file 1: Annex 1, as a robustness check. Parameter estimates in bold denote those variables with a stable effect, in terms of sign and significance, across the models.

There are some variables that had an effect on intra-family farm succession robust across various specifications in terms of sign and significance. The graduation of farm-holders exerts a negative effect on the probability of farm succession, in contrast to the results of Simeone (2006), who examined a sample of 100 farmers in central Italy but in line with some studies that used a similar proxy, considering parents with at least a high school diploma (Corsi 2009; Mishra et al. 2010). Different effects of the same variable may be explained by the specificity of the contexts examined. More generally, a possible explanation of the present results relies on a higher probability that a graduate farmer pushes his/her children to graduate, and graduation, especially in non-agricultural subjects, would increase their propensity to abandon agricultural activity.

The probability of farm succession is higher for older farms (coefficient positive and linear, consistent with Bertoni and Cavicchioli 2016a). Specialization in fruit or ready-prepared fresh vegetables results in the probability of having successors negative or positive, respectively. The coefficient of the share of hired work is negative and consistent with Kerbler (2008), who tested the same variable on a sample of 789 Slovenian farmers. Additionally, farm size had a stable effect on succession, even if divergent in financial and structural terms. Succession probability is lower in farms 
Table 3 Theoretical confusion matrix comparing the number of events observed and predicted by an estimated model

\begin{tabular}{|c|c|c|c|c|}
\hline \multicolumn{2}{|c|}{ Predicted/observed farm succession events } & \multicolumn{3}{|c|}{ Observed farm succession events } \\
\hline & & $\begin{array}{l}\text { Farm succession } \\
\text { takes place }\end{array}$ & $\begin{array}{l}\text { Farm succession does } \\
\text { not take place }\end{array}$ & $\begin{array}{l}\text { Total observed farm } \\
\text { succession events }\end{array}$ \\
\hline \multirow[t]{3}{*}{$\begin{array}{l}\text { Predicted farm } \\
\text { succession events }\end{array}$} & $\begin{array}{l}\text { Farm succession } \\
\text { takes place }\end{array}$ & A & B & $A+B$ \\
\hline & $\begin{array}{l}\text { Farm succession does } \\
\text { not take place }\end{array}$ & C & $\mathrm{D}$ & $C+D$ \\
\hline & $\begin{array}{l}\text { Total predicted farm } \\
\text { succession events }\end{array}$ & $A+C$ & $B+D$ & N \\
\hline
\end{tabular}

Table 4 Results of probit regression

\begin{tabular}{|c|c|c|c|}
\hline & $\begin{array}{l}\text { Farm and farmer variables; no labour } \\
\text { market and surrounding condition } \\
\text { (LMSC) variables (model 3) }\end{array}$ & $\begin{array}{l}\text { Farm and farmer } \\
\text { variables; LMSC variables } \\
\text { in linear form (model 4) } \\
\end{array}$ & $\begin{array}{l}\text { Farm and farmer variables; } \\
\text { LMSC variables in non- } \\
\text { linear form (model 7) } \\
\end{array}$ \\
\hline Farmer age & 0.0121 & 0.0118 & $-0.1481^{*}$ \\
\hline Farmer age_sq & - & - & $0.0013^{*}$ \\
\hline Farmer degree & $-0.9126^{* * *}$ & $-0.9698^{* * *}$ & $-0.8957^{* * *}$ \\
\hline Farmer children & 0.0372 & 0.092 & $0.1379^{* *}$ \\
\hline Turnover_250 & $-0.3030^{*}$ & $-0.3309^{*}$ & $-0.3785^{* *}$ \\
\hline Farm duration & $0.0116^{* * *}$ & $0.0108^{* * *}$ & $0.01^{* * *}$ \\
\hline RPFV farm & $0.8196^{* *}$ & 0.4348 & $0.8985^{* * *}$ \\
\hline Fruit farm & $-1.3773^{* * *}$ & $-1.2117^{* *}$ & $-1.1348^{* *}$ \\
\hline Emplwork & $-0.0108^{* * *}$ & $-0.0113^{* *}$ & $-0.0104^{*}$ \\
\hline Workdays & $0.0007^{* *}$ & $0.0006^{* *}$ & $0.0007^{* *}$ \\
\hline Workdays_sq & $0.0000^{* *}$ & $0.0000^{*}$ & $0.0000^{* *}$ \\
\hline Distance & $0.0080^{* *}$ & -0.0004 & $-0.0008^{* * *}$ \\
\hline Distance_sq & $0.0000^{* *}$ & - & - \\
\hline Popdens & - & 0.0000 & $-0.0036^{* * *}$ \\
\hline Popdens_sq & - & - & $0.0000^{* * *}$ \\
\hline Empl & - & 0.0164 & $2.7195^{* * *}$ \\
\hline Empl_sq & - & - & $-0.025^{* * *}$ \\
\hline Agrshare & - & $-11.2887^{* * *}$ & -4.8662 \\
\hline Incgap & - & $0.1382^{* * *}$ & $-1.3349^{* * *}$ \\
\hline Incgap_sq & - & & $0.0335^{* * *}$ \\
\hline Hills & 0.7892 & $1.9286^{* * *}$ & $2.3695^{* * *}$ \\
\hline Mountain & $1.4278^{* * *}$ & -1.1795 & $-10.8799^{* * *}$ \\
\hline Campania & $0.6311^{*}$ & 1.0965 & $7.0349^{* * *}$ \\
\hline Piemonte & $-1.291^{* * *}$ & $-2.2433^{* * *}$ & $-7.041^{* * *}$ \\
\hline Veneto & 0.1133 & $2.6116^{* * *}$ & $1.6324^{* *}$ \\
\hline Emilia-Romagna & -0.0911 & 0.5548 & -0.9747 \\
\hline Constant & $-1.8808^{* * *}$ & -5.0828 & $-57.2248^{* *}$ \\
\hline $\mathrm{N}$ obs & 259 & 259 & 259 \\
\hline Pseudo $R^{2}$ & $23 \%$ & $26 \%$ & $30 \%$ \\
\hline
\end{tabular}

*** and ${ }^{* * *}$, denote significance at $10 \%, 5 \%$ and $1 \%$, respectively

The table reports three of seven different model specifications. The complete version with all the models is presented in Additional file 1: Annex 1

The parameter estimates whose sign and significance are stable across different specifications are presented in italics (those not presented in Table 3 are available as supplemental material) 
with turnover beyond 250,000 euros, which is not consistent with previous findings (Mishra and El-Osta 2008; Aldanondo Ochoa et al. 2007). On the other hand, a stable positive effect of the structural dimensions of a farm, approximated by the number of workdays, is observable.

As occupational choice theory suggests a linear effect of LMSC variables on labour migration (and then, in the opposite manner, on succession), LMSC variables have been entered in linear terms (model 4), finding a positive linear role of income gap (between agricultural and non-agricultural sectors), negative linear role of share of agricultural employment and non-significant effect of employment rate and population density. According to the second research question (and in line with Bertoni and Cavicchioli 2016a and Cavicchioli et al. 2018), the non-linear effects of such variables have been explored. Thus, three (income gap, employment rate and population density) of the four LMSC variables were significant both in linear and in squared terms, while the share of agricultural employment was not significant (neither linear nor squared). In line with similar previous findings (Bertoni and Cavicchioli 2016a; Cavicchioli et al. 2018), the explanation of such results relies on a combination of pro-succession and anti-succession effects due to the specific features of such farms. The pro-succession effects of LMSC variables rely on increased market opportunities for fruit and vegetable farms nearer to densely populated and wealthier areas (having higher employment rates and larger income gaps compared to agricultural areas). Another possible explanation of pro-succession effects relies on better services for the family farm that would be encouraged to continue its activity. The anti-succession effects exerted by LMSC variables are those predicted by the occupational choice theory: if increasing values of Popdens, Empl and Incgap favor out-farm migration, then for the same reason, they will discourage farm succession. Interestingly, the introduction of LMSC variables restored the significance of some farm and farmer variables: farmer age (non-linear $\mathrm{u}$ shaped, even if significant at 10\%), number of children in the family farm (positive, in line with Mann 2007 but in contrast to Aldanondo Ochoa et al. 2007 and Cavicchioli et al. 2015), distance of the farm from the producers organization where the product is delivered (negative, in line with Aldanondo Ochoa et al. 2007) and farm location in hilly areas (positive, in line with Corsi 2009, in contrast to Glauben et al. 2004). The same effect occurred with the regional dummy Campania, whose magnitude and significance increase consistently. Furthermore, farm location in mountainous areas changed sign (from positive to negative, increasing its magnitude) after the inclusion of contextual variables. The results presented point to a non-linear effect of LMSC variables on farm succession, as in the linear specification (model 4) where only two of the four LMSC variables were significant.

To compare the different models presented and to explore the contribution of the LMSC variables in improving farm succession predictions, some post-estimation statistics for model comparisons have been carried out. The statistics are presented in Table 5 for models 3, 4 and 7, while the same statistics for all the estimated models are available in Additional file 1: Annex 2. An explanation description of the statistics presented in Table 5 is included in the last part of the "Methodology" section.

The model evaluation and comparison criteria provide three main results. 
Table 5 Post-estimation statistics for model comparison

\begin{tabular}{llll}
\hline & $\begin{array}{l}\text { Farm and farmer variables; no labour } \\
\text { market and surrounding conditions } \\
(\text { LMSC) variables (model 3) }\end{array}$ & $\begin{array}{l}\text { Farm and farmer } \\
\text { variables; LMSC variables } \\
\text { in linear form (model 4) }\end{array}$ & $\begin{array}{l}\text { Farm and farmer variables; } \\
\text { LMSC variables in } \\
\text { non-linear form (model 7) }\end{array}$ \\
\hline Pseudo $R^{2}$ & $23 \%$ & $26 \%$ & $30 \%$ \\
Sensitivity & $65 \%$ & $62 \%$ & $65 \%$ \\
Specificity & $82 \%$ & $83 \%$ & $87 \%$ \\
Correctly classified & $75 \%$ & $74 \%$ & $77 \%$ \\
AIC & 312 & 306 & 295 \\
BIC & 379 & 384 & 380 \\
\hline
\end{tabular}

Post-estimation statistics for models 1, 25 and 6 are available in Additional file 1: Annex 2

First, for each of the McFadden's $R$-squared measures reported in Table 5 and Additional file 1: Annex 2, there is substantial agreement that model 7 fits the outcome data better than the other models.

Second, the AIC and BIC are minimized in models 7 and 1, respectively. This outcome is not surprising because BIC penalizes model complexity more heavily, which is consistent with the larger number of estimated parameters involved in model 7 (having LMSC variables in level and squared) than in model 1.

Third, the results from the confusion matrix allow us to compare the sensitivity, specificity and accuracy for each model at a 0.5 cut-off value. These three indicators have the advantage of assessing the performance of each model in terms of actual and predicted classifications without being affected by the proportion of farms with succession. Table 5 shows that despite models 1 and 7 providing the same percentage of sensitivity (65\%), the inclusion of the LMSC variables improves the specificity and the accuracy of the outcome variable.

Overall, for this analysis, model 7 offers the best fit among the set of candidate models, and therefore, the inclusion of LMSC variables offers better farm succession predictions.

\section{Concluding remarks}

The aim of this paper was to explore whether and to what extent the inclusion of labour market and surrounding conditions (LMSC) variables may improve a farm succession analysis. The reason for including such a category of determinants relies on the already identified intuition that family business transfer may be viewed as an alternative decision of potential heir(s) compared to finding employment outside of the agricultural sector.

According to OCT, the latter decision is affected by LMSC variables. The above-mentioned research question has been addressed empirically by estimating various models that predict farm succession probability. One model was estimated that included only farm and farmer features (and without LMSC variables), while in the second and third models, LMSC variables were included in linear and non-linear form, respectively. In the second model (linear), only two LMSC variables were significant, while in the third model (non-linear), three of the LMSC variables were significant, suggesting that the relationship between farm succession and LMSC variables may be better modelled in a non-linear fashion rather than as a linear relationship. From the model comparison, a block of variables emerged (Farmer children, Farm duration, Fruit farm, Emplwork and Workdays) whose effect was robust across specification, while the 
introduction of LMSC variables restored the significant effect of some other variables (Hills) and changed the sign of some others (Mountain). To investigate and compare the accuracy of different model specifications (excluding and including LMSC variables), some post-estimation and model fitting tests were performed. The model including LMSC variables in a non-linear form emerged as a better fit in terms of the actual event of farm succession in terms of pseudo $R$-squared, specificity, share of correct predictions and one of two information criteria (AIC). For this reason, the present empirical findings suggest that farm succession analyses are improved by including LMSC variables.

As stated in the data description, given the specific composition of the sample (fruit and vegetable farms belonging to a PO consortium) and the lack of data on PO affiliations in the underlying population of these farms, both sample representativeness and result extendibility are not straightforward. Thus, the present analysis should be repeated on different types of farms and in different areas to obtain a better picture of the effect of LMSC variables on farm succession. However, the contribution of the present findings goes beyond the underlying population of our sample (farms members of POs or fruit and vegetable farms) as it may provide various implications for farm succession analyses and potentially for farm labour migration studies. First, contextual variables (LMSC variables) play a role when analyzing the probability of intra-family farm succession, improving model fit and predictions; second, in specific cases, such as those examined, the effect of LMSC variables on intra-family transfer is non-linear, unlike those expected by occupational choice theory; third, the inclusion of contextual variables may change the significance and/or sign of some farm and farmer variables on succession probability. These implications suggest considering intra-family farm transfer as part of a wider problem of labour allocation choice in the agricultural sector that cannot be examined in isolation with respect to labour, population and economic patterns of other sectors. Furthermore, potential non-linear effects of labour market and contextual variables should be explored and taken into account not only in farm succession analysis but also in empirical estimations based on occupational choice theory, for instance, in the assessment of the labour effect of agricultural policy. Finally, the present study indirectly points to the lack of a clear and unifying theoretical framework underpinning the empirical analysis of family farm features affecting succession (child, farmer and farm features). Such an in-farm theoretical framework of succession should be clearly defined to match the out-farm migration framework suggested by occupational choice theory.

\section{Additional file}

Additional file 1: Annex 1 -Robustness Check across different specifications. Annex 2 - Post-estimation statistics for comparison of the 7 estimated models. (DOCX $23 \mathrm{~kb}$ )

\section{Acknowledgements}

The present work would not have been possible without data gathered during the research project "AOP UNOLOMBARDIA: il primario avanzato-Progetto per lo sviluppo di una struttura a rete cheassista la 'coopetizione' tra le filiere ortofrutticole aderenti ad AOPUNOLOMBARDIA" undertaken by the Rural Development Program of the Lombardy Region 2007-2013.

Funding

Not applicable 


\section{Authors' contributions}

The research design was conceived by DC and DB. Data gathering has been carried out by DGF and RP. The "Background" section has been written by DC and DB, the "Data and variables" section by DB, the "Methodology" section by DC, the "Results and discussion" section by DC and the "Concluding remarks" by DC, DB, DGF and RP. All the authors read and approved the final manuscript.

\section{Competing interests}

The authors declare that they have no competing interests.

\section{Publisher's Note}

Springer Nature remains neutral with regard to jurisdictional claims in published maps and institutional affiliations.

Received: 30 July 2018 Accepted: 7 May 2019

Published online: 23 May 2019

\section{References}

Akaike H (1974) A new look at the statistical model identification. IEEE Trans Autom Control 19(6):716-723. https://doi.org/10. 1109/TAC.1974.1100705

Alasia A, Weersink A, Bollman R D, Cranfield J (2009) Off-farm labour decision of Canadian farm operators: urbanization effects and rural labour market linkages. J Rural Stud 25, 12-24. https://doi.org/10.1016/j.jrurstud.2008.04.002.

Aldanondo Ochoa AM, Casanovas Olivy V, Valmansa Sáez C (2007) Explaining farm succession: the impact of farm location and off-farm employment opportunities. Span J Agric Res 5(2):214-225. https://doi.org/10.5424/sjar/2007052-241

Barkley AP (1990) The determinants of the migration of labor out of agriculture in the United States, 1940-85. Am J Agric Econ 72(3):567-573. https://doi.org/10.2307/1243025

Bednaríková Z, Bavorová M, Ponkina EV (2016) Migration motivation of agriculturally educated rural youth: the case of Russian Siberia. Journal of Rural Studies 45:99-111. https://doi.org/10.1016/j.jrurstud.2016.03.006

Bertoni D, Cavicchioli D (2016a) Farm succession, occupational choice and farm adaptation at the rural-urban interface: the case of Italian horticultural farms. Land Use Policy 57:739-748. https://doi.org/10.1016/j.landusepol.2016.07.002

Bertoni D, Cavicchioli D, Latruffe L (2017) Performance post succession on Italian family farms. In: XV EAAE Congress "Towards Sustainable Agri-food Systems: Balancing Between Markets and Society". Anais, Parma, pp 1-14

Bertoni D, Cavicchioli D (2016b) Process description, qualitative analysis and causal relationships in farm succession. Perspect Agric Vet Sci Nutr Nat Resour 11(43):1-11. https://doi.org/10.1079/PAVSNNR201611043

Bertoni D, Cavicchioli D, Pretolani R, Olper A (2011) Agri-environmental measures adoption: new evidence from Lombardy region. In: Sorrentino A, Severini S, Henke R (eds) The Common Agricultural Policy after the Fischler Reform: National Implementations, Impact Assessment and the Agenda for Future Reforms. Ashgate Publishing, Surrey, pp 275-294

Bjarnason T, Thorlindsson T (2006) Should I stay or should I go? Migration expectations among youth in Icelandic fishing and farming communities. J Rural Stud 22(3):290-300. https://doi.org/10.1016/j.jrurstud.2005.09.004

Burton RJ, Fischer H (2015) The succession crisis in European agriculture. Sociol Rural 55(2):155-166

Carillo F, Carillo MR, Venittelli T, Zazzaro A (2013) Aging and succession on Italian farms. pagri/iap, p 39

Cavicchioli D, Bertoni D, Pretolani R (2018) Farm succession at a crossroads: the interaction among farm characteristics, labour market conditions, and gender and birth order effects. J Rural Stud 61:73-83. https://doi.org/10.1016/j.jrurstud.2018.06.002

Cavicchioli D, Bertoni D, Tesser F, Frisio DG (2015) What factors encourage intrafamily farm succession in mountain areas? Evidence from an alpine valley in Italy. Mt Res Dev 35(2):152-160. https://doi.org/10.1659/MRD-JOURNAL-D-14-00107.

Chen R, Ye C, Cai Y, Xing X, Chen Q (2014) The impact of rural out-migration on land use transition in China: past, present and trend. Land Use Policy 40:101-110. https://doi.org/10.1016/j.landusepol.2013.10.003

Chiswell HM (2018) From generation to generation: changing dimensions of intergenerational farm transfer. Sociol Rural 58(1):104-125. https://doi.org/10.1111/soru.12138

Chiswell HM, Lobley M (2015) A recruitment crisis in agriculture? A reply to Heike Fischer and Rob JF Burton's understanding farm succession as socially constructed endogenous cycles. Sociol Rural 55(2):150-154. https://doi.org/10.1111/soru.12071

Corsi A (2009) Family farm succession and specific knowledge in Italy. Riv Econ Agrar 64(1-2):13-30

Demartini E, Gaviglio A, Bertoni D (2015) Integrating agricultural sustainability into policy planning: a geo-referenced framework based on Rough Set theory. Environ Sci Pol 54:226-239. https://doi.org/10.1016/j.envsci.2015.07.006

Errington A (1998) The intergenerational transfer of managerial control in the farm-family business: a comparative study of England, France and Canada. J Agric Educ Ext 5(2):123-136. https://doi.org/10.1080/13892249885300241

Glauben T, Petrik M, Tietje T, Weiss CR (2009) Probability and timing of succession or closure in family firms: a switching regression analysis of farm households in Germany. Appl Econ 41:45-54. https://doi.org/10.1080/00036840601131722

Glauben T, Tietje H, Weiss C (2006) Agriculture on the move: exploring regional differences in farm exit rates in Western Germany. Rev Reg Res 26:103-118. https://doi.org/10.1007/s10037-004-0062-1

Glauben T, Tietje T, Weiss C R (2004) Intergenerational succession in farm households: evidence from Upper Austria. Rev Econ Househ. 2:443-461. https://doi.org/10.1007/s11150-004-5656-4.

Graeub BE, Chappell MJ, Wittman H, Ledermann S, Kerr RB, Gemmill-Herren B (2016) The state of family farms in the world. World Dev 87:1-15. https://doi.org/10.1016/j.worlddev.2015.05.012

Grubbström A, Stenbacka S, Joosse S (2014) Balancing family traditions and business: gendered strategies for achieving future resilience among agricultural students. J Rural Stud 35:152-161. https://doi.org/10.1016/j.jrurstud.2014.05.003

Hamilton W, Bosworth G, Ruto E (2015) Entrepreneurial younger farmers and the "Young Farmer Problem" in England. Agric Forestry 61(4):61-69. https://doi.org/10.17707/AgricultForest.61.4.05

Harris JR, Todaro MP (1970) Migration, unemployment and development: a two-sector analysis. Am Econ Rev 60(1):126-142 Retrived from: https://www.jstor.org/stable/1807860

Johansson M (2016) Young women and rural exodus-Swedish experiences. J Rural Stud 43:291-300. https://doi.org/10. 1016/j.jrurstud.2015.04.002 
Kerbler B (2008) The influence of factors of the socio-geographical structure of mountain farms in Slovenia upon farm succession statuses and decisions. Acta Geographica Slovenica 48(2):278-292. https://doi.org/10.3986/AGS48203

Kimhi A, Nachlieli N (2001) Intergenerational succession on Israeli family farms. J Agric Econ 52(2):42-58. https://doi.org/10. 1111/j.1477-9552.2001.tb00924.x

Larson D, Mundlak Y (1997) On the intersectoral migration of agricultural labour. Econ Dev Cult Change 45(January):295-319 Retrieved from http://www.jstor.org/stable/1154537

Leibert T (2016) She leaves, he stays? Sex-selective migration in rural East Germany. J Rural Stud 43:267-279. https://doi.org/ 10.1016/j.jurstud.2015.06.004

Leonard B, Kinsella A, O'Donoghue C, Farrell M, Mahon M (2017) Policy drivers of farm succession and inheritance. Land Use Policy 61:147-159. https://doi.org/10.1016/j.landusepol.2016.09.006

Lobley M, Baker JR, Whitehead I (2010) Farm succession and retirement: some international comparisons. J Agric Food Syst Commun Dev 1(1):49-64. https://doi.org/10.5304/jafscd.2010.011.009

MacDonald D, Crabtree JR, Wiesinger G, Dax T, Stamou N, Fleury P, Gutierrez Lazpita J, Gibon A (2000) Agricultural abandonment in mountain areas of Europe: environmental consequences and policy response. J Environ Manag 59(1): 47-69. https://doi.org/10.1006/jema.1999.0335

Mann S (2007) Tracing the process of becoming a farm successor on Swiss family farms. Agric Hum Values 24(4):435-443. https://doi.org/10.1007/s10460-007-9087-8

McDonald R, Macken-Walsh Á, Pierce K, Horan B (2014) Farmers in a deregulated dairy regime: insights from Ireland's New Entrants Scheme. Land Use Policy 41:21-30. https://doi.org/10.1016/j.landusepol.2014.04.018

McElwee G, Bosworth G (2010) Exploring the strategic skills of farmers across a typology of farm diversification approaches. J Farm Manage 13(12):819-838

McFadden DS (1973) Conditional logit analysis of qualitative choice behavior. In: P., Zarembka (ed) Frontiers in econometrics. Academic Press, New York

Mishra AK, El-Osta HS (2008) Effects of agricultural policy on succession decisions of farm households. Rev Econ Household 6 : 285-307. https://doi.org/10.1007/s11150-008-9032-7

Mishra AK, El-Osta HS, Shaik S (2010) Succession decisions in US family farm businesses. J Agric Resour Econ 35(1):133-152 Retrieved from: https://tind-customer-agecon.s3.amazonaws.com/97e7c08d-71fd-4674-be57-aa3afbe7b73a?responsecontent-disposition=inline\%3B\%20filename\%3D\%22JARE_Apr2010_09_pp133-152.pdf\%22\&response-content-type= application\%2Fpdf\&AWSAccessKeyld=AKIAXL7W7Q3XHXDVDQYS\&Expires=1558465164\&Signature= cbe97dsplGexfadnrket8rlmFko\%3D

Morais M, Binotto E, Borges JAR (2017) Identifying beliefs underlying successors' intention to take over the farm. Land Use Policy 68:48-58. https://doi.org/10.1016/j.landusepol.2017.07.024

Morais M, Borges JAR, Binotto E (2018) Using the reasoned action approach to understand Brazilian successors' intention to take over the farm. Land Use Policy 71:445-452. https://doi.org/10.1016/j.landusepol.2017.11.002

Mundlak Y (1978) Occupational migration out of agriculture: a cross-country analysis. Rev Econ Stat 60 (3), 392-398. https:// doi.org/10.2307/1924164.

Ohe Y (2018) Educational tourism in agriculture and identity of farm successors. Tour Econ 24(2):167-184. https://doi.org/10. $1177 / 1354816617729021$

Olper A, Raimondi V, Cavicchioli D, Vigani M (2014) Do CAP payments reduce farm labour migration? A panel data analysis across EU regions. Eur Rev Agric Econ 41(5):843-873. https://doi.org/10.1093/erae/jbu002

Paracchini ML, Bulgheroni C, Borreani G, Tabacco E, Banterle A, Bertoni D, Rossi G, Parolo G, Origgi R, De Paola C (2015) A diagnostic system to assess sustainability at a farm level: the SOSTARE model. Agric Syst 133:35-53. https://doi.org/10.1016/j.agsy.2014.10.004

Provost, F.., Fawcett, T., Kohavi, R. (1998). The case against accuracy estimation for comparing induction algorithms. In: ICML (Vol. 98, pp. 445-453).

Raggi M, Sardonini L, Viaggi D (2013) The effects of the Common Agricultural Policy on exit strategies and land re-allocation. Land Use Policy 31:114-125. https://doi.org/10.1016/j.landusepol.2011.12.009

Schwarz G (1978) Estimating the dimension of a model. Ann Stat 6(2):461-464. https://doi.org/10.1214/aos/1176344136

Simeone M (2006) Le determinanti del trasferimento intergenerazionale in agricoltura: un'analisi empirica basata sulla stima di un modello probit. Riv Econ Agrar, LXI (4):519-539 ISSN 0035-6190

Stenholm P, Hytti U (2014) In search of legitimacy under institutional pressures: a case study of producer and entrepreneur farmer identities. J Rural Stud 35:133-142. https://doi.org/10.1016/j.jrurstud.2014.05.001

Stiglbauer A, Weiss CR (2000) Family and non-family succession in the Upper Austria farm sector. Cahiers d'Économie et Sociologie Rurales 54:5-26 Retrieved from hal-01200950

Suess-Reyes J, Fuetsch E (2016) The future of family farming: a literature review on innovative, sustainable and successionoriented strategies. J Rural Stud 47:117-140. https://doi.org/10.1016/j.jurstud.2016.07.008

Todaro MP (1969) A model of labour migration and urban unemployment in less developed countries. Am Econ Rev 59:138-148

Uchiyama T, Lobley M, Errington A, Yanagimura S (2008) Dimensions of intergenerational farm business transfers in Canada, England, the USA and Japan. Japanese J Rural Econ 10:33-48. https://doi.org/10.18480/jjre.10.33

Van Passel S, Nevens F, Mathiis E, Van Huylenbroeck G (2007) Measuring farm sustainability and explaining differences in sustainable efficiency. Ecol Econ 62(1):149-161. https://doi.org/10.1016/j.ecolecon.2006.06.008

Väre M, Pietola K, Weiss CR (2010) The irrelevance of stated plans in predicting farm successions in Finland. Agric Food Sci 19:81-95

Vesala HT, Vesala KM (2010) Entrepreneurs and producers: identities of Finnish farmers in 2001 and 2006. J Rural Stud 26(1): 21-30. https://doi.org/10.1016/j.jurstud.2009.06.001

Zagata L, Sutherland LA (2015) Deconstructing the 'young farmer problem in Europe': towards a research agenda. J Rural Stud 38:39-51. https://doi.org/10.1016/j.jurstud.2015.01.003 